\title{
"Com defunto ruim não se gasta vela": hierarquizações que recaem sobre vítimas e réus na administração de conflitos no Tribunal do Júri do Rio de Janeiro'
}

\author{
"Bad corpses aren't worth good candles": hierarchical \\ structures on the victims and defendants during conflict \\ resolution in the Jury Court of Rio de Janeiro
}

\section{Izabel Saenger Nuñez}

Brasil. Universidade Federal Fluminense. Doutora em Antropologia pelo PPGA da Universidade Federal Fluminense (UFF). Mestre em Ciências Jurídicas e Sociais pelo PPGSD/UFF. Bacharel em Ciências Jurídicas e Sociais pela Pontifícia Universidade Católica do Rio Grande do Sul (PUC-RS). Atualmente, é pesquisadora de pós-doutorado (PNPD/CAPES) no PPGA/UFF e do Instituto Nacional de Estudos Comparados em Administração Institucional de Conflitos (INCT-InEAC). ID ORCID: https://orcid.org/0000-0003-4985-9054.E-mail: izabelsn@gmail.com.

\section{Resumo}

Este artigo apresenta a forma como diferentes classificações acionadas pelos agentes do Estado que operam no Tribunal do Júri, isto é, no sistema de justiça criminal, recaem sobre vítimas e réus, produzindo hierarquizações sobre seus casos, suas personalidades, suas vidas e respectivas mortes. A partir dessas classificações morais, atribuem a eles diferentes sentidos quanto à categoria "humanos" e quanto aos direitos correspondentes eventualmente atribuídos a eles ou deles retirados, tal como previstos na legislação abstrata. A partir da descrição de dois casos observados durante o trabalho de campo realizado ao longo de um ano e meio em tal contexto, procuro evidenciar como tais classificações se entrecruzam, atribuindo diferentes valores morais às pessoas envolvidas nos casos e dando a eles diferentes soluções possíveis, por meio das interações entre agentes e as partes e das moralidades eivadas dessas interações.

Palavras-chave: Administração de Conflitos, Tribunal do Júri, Moralidades, Mortes, Mortos.

Apresentei versão preliminar desse texto, focada especificamente nas convergências morais, na $30^{\mathrm{a}}$ Reunião Brasileira de Antropologia, realizada no ano de 2016. Agradeço aos comentários das coordenadoras do GT, Lucía Eilbaum e Patrice Schuch, que permitiram o seu aprofundamento. Ainda, agradeço aos comentários dos pareceristas da revista pelas contribuições. 


\section{Abstract}

This paper shows how different classifications are triggered by the state agents operating in the Jury Court and their effect on victims and defendants, producing hierarchical structures over their cases as well as their respective mourned victims' deaths, which affect their conception about humans. By describing two cases observed in fieldwork performed over a year and a half, the way these classifications intersect is demonstrated, assigning different moral values to the people involved in the cases and bringing out different solutions, while agents interact between themselves and each party.

Keywords: Conflicts Administration, Trial by Jury, Moralities, Murders, Deaths.

\section{INTRODUÇÃO}

Nesse trabalho, pretendo demonstrar, por meio da descrição de minhas observações em uma Vara do Tribunal do Júri da Comarca do Rio de Janeiro, as hierarquizações feitas sobre as vítimas e os réus durante a administração de conflitos, com foco nas classificações morais identificadas por mim nos discursos dos agentes do sistema de justiça criminal. Tais classificações são decorrentes das representações a respeito desses homens e mulheres durante a prestação jurisdicional. Para tanto, contrasto dois casos lá julgados: o primeiro, de Maria Silva², ou a "cracuda" e, o segundo, de "Bruno Eusébio". Além dos julgamentos morais que recaem sobre as vítimas, procuro evidenciar o que chamei de "convergência moral" sobre os desfechos dos casos e suas soluções possíveis (VILLALTA; CIORDIA, 2010) ${ }^{3}$. Estas "convergências" levavam à realização de "acordos" entre promotores e defensores públicos nas audiências e julgamentos, a depender do que eventualmente os casos mobilizam neles. Especialmente o caso da "cracuda"

\footnotetext{
2 Todos os nomes dos envolvidos nos casos foram modificados, exceto aqueles referentes ao caso "Bruno Eusébio" que, por se tratar de um caso de repercussão (EILBAUM; LIMA; MEDEIROS, 2017), foi amplamente publicizado.

3 Não é objeto deste artigo compreender ou buscar analisar o fenômeno da violência (MISSE 2016; ZALUAR, 1999). Nesse sentido, se a maneira como o caso de Maria, a "cracuda", foi tratado pelo poder judiciário está ligada às representações contemporâneas sobre o fenômeno - que, até recentemente, não era objeto de estudo das ciências sociais sob a perspectiva hoje.
} 
mostra como a humanidade da vítima pode ser manipulada e até mesmo afastada. O outro caso, ao contrário, aproxima o réu da sua dimensão "humana" em razão dos valores morais (BALBI, 2007) que desperta no promotor, defensor e magistrado.

A metodologia utilizada para a realização desta pesquisa é a da etnografia ${ }^{4}$ (OLIVEIRA, 1996), principalmente a partir da observação de rotinas de trabalho no Tribunal do Júrí. Ao longo do trabalho de campo, acompanhei as atividades dos profissionais que lá atuam, ou seja, defensores públicos, promotores e assessores dos juízes em seus gabinetes, assim como nas sedes da Defensoria Pública e do Ministério Público, localizadas fora do Foro Central, porém também no centro do Rio de Janeiro. E essa observação foi muito rica porque, diferentemente de muitas etnografias e pesquisas que focaram no ritual do plenário (SCHRITIZMEYER, 2001), observei igualmente o trabalho prévio daqueles que lá atuam e busquei identificar o que há de cotidiano - e não de excepcional - nessa forma de julgar.

A rotina no Júri consiste não apenas nas movimentações processuais dos casos produzidas nos gabinetes e nos cartórios ${ }^{6}$, mas também na realização das audiências de instrução e julgamento que ocorrem de uma a três vezes por semana e, por fim, nas sessões plenárias. Tais sessões, assim como as audiências, são abertas ao público em geral, e consistem em rituais judiciários durante os quais os réus, acusados de cometer "homicídios" ou "tentativas de homicídios", são julgados por sete jurados leigos. Assim, pude perceber que,

\footnotetext{
4 Este trabalho é parte de uma reflexão mais ampla desenvolvida em minha tese de doutorado, defendida em 2018 no âmbito do Programa de Pós-Graduação em Antropologia da UFF, uma etnografia sobre o "fazer judicial" (EILBAUM, 2012) no Tribunal do Júri, que acontece cotidiana e diariamente. Destaco que, durante os julgamentos, buscava transcrever em meu caderno de campo as falas literais dos agentes. Falas estas que foram inseridas nesse artigo, de modo a demonstrar a construção moral sobre os envolvidos nos casos. No entanto, por conta do formato dinâmico da atividade, muitas vezes não foi possível anotá-las na sua integralidade.

5 O Tribunal do Júri é um procedimento penal especial previsto no artigo $5^{\circ}$ da Constituição Federal e no Código de Processo Penal brasileiro (art. 406 e seguintes) utilizado exclusivamente para os crimes dolosos contra a vida e que difere dos outros procedimentos existentes no processo penal brasileiro. Uma das diferenças reside em sua forma oral e conta com a participação de sete jurados "leigos" para a produção da verdade e elaboração da decisão final do processo. Vão a júri, portanto, os "crimes dolosos contra a vida”, sendo eles: a) homicídio; b) infanticídio; c) induzimento, instigação ou auxílio ao suicídio; d) aborto. Essa característica fala sobre a "sensibilidade jurídica" (GEERTZ, 2007) inquisitorial da sociedade brasileira e especialmente reproduzida no sistema de justiça criminal (KANT DE LIMA, 2010).

6 Tais como a elaboração de decisões “interlocutórias", isto é, aquelas que não acabam com o processo, mas que fazem com que ele tenha prosseguimento e chegue ao final, o recebimento das denúncias pelo juiz, o agendamento e preparação das audiências, o registro de ofícios e petições por parte do cartório e do gabinete do juiz.
} 
diante do que cada caso desperta nos agentes que atuam no Júri, eles podem ser administrados de diferentes formas, mostrando a maneira como procedimentos burocráticos podem ser subvertidos pelo acionamento de diferentes moralidades situacionais (EILBAUM, 2012).

Especialmente para a organização do material empírico e para evidenciar contrastes entre o que foi observado por mim ao longo de todo o trabalho de campo, estruturei o artigo através da exposição dos dois casos que explicitam as relações entre as pessoas do grupo e, embora sejam apresentados isoladamente, permitem exprimir, por conta da observação mais ampla, as rotinas e as exceções acompanhadas durante a pesquisa. Ademais, "caso" é também a categoria ordenadora do trabalho no contexto de instituições policiais e judiciárias como uma categoria nativa. Isso porque eles se referem aos "casos" com os quais trabalham, elegendo-os como mais ou menos relevantes e dando conta de sua construção policial e jurídica (EILBAUM, 2012). Assim, funcionam aqui tanto como ferramentas empíricas quanto analíticas ${ }^{7}$. Por tudo isso, é possível compreender como afetam os agentes de diferentes formas e acionam maior ou menor investimento de recursos por parte deles.

Nesse sentido, transcendem os processos e os "autos" e reúnem mais que elementos jurídicos, mas também as interpretações que esses homens e mulheres que operam o poder judiciário fazem sobre eles, em interação. Significa dizer, então, que foram escolhidos a partir do exame de uma série de incidentes específicos ligados às mesmas pessoas, isto é, ao grupo profissional cujo trabalho observei de modo contínuo. Ao selecioná-los para este artigo, busco demonstrar como esses incidentes (GLUCKMAN, 1975) se ligam ao desenvolvimento das relações sociais estabelecidas entre os agentes, analisando como eles atribuem sentido ao que fazem e como interagem para dar conta do fazer judicial. Ou seja, os "casos"

Empíricas porque organizam o material de campo, dando forma para a sua apresentação. Analíticas porque explicitam os dados e permitem a compreensão e elucidação daquilo que foi observado em razão do acompanhamento de uma série de incidentes específicos ligados às mesmas pessoas e grupos. Especificamente, tomei como norte o discurso dos agentes do poder judiciário sobre os casos para pensar como eram administrados, demonstrar as determinadas reações que acionavam e, assim, o que demonstravam. Não trabalhei com os envolvidos nos casos, isto é, não entrevistei réus, vítimas e seus familiares. Somente me ative aos casos desde o olhar do poder judiciário. Essa estratégia metodológica e teórica tem sido adotada por outros pesquisadores que investigam o estado e o poder judiciário, como CARRARA; VIANNA, 2006; EILBAUM, 2012; FERREIRA, 2015; LACERDA, 2014; VEIGA, 2015. 
explicitam as relações entre as pessoas do grupo e, embora sejam apresentados isoladamente, permitem demonstrar as rotinas e as exceções identificadas nas práticas que acompanhei ao longo da pesquisa.

Do ponto de vista de sua classificação jurídica, dentro do sistema de justiça criminal brasileiro, o Tribunal Júri é um "procedimento especial" previsto no sistema processual penal que serve para "processar e julgar" apenas alguns crimes. Isto é, trata-se de uma forma de processar e administrar conflitos, dirigida não a todos os casos criminais, mas somente ao julgamento dos chamados "crimes dolosos contra a vida". Tal classificação nativa implica, consequentemente, classificação e hierarquização (DUMONT, 1997, p. 373; DURKHEIM; MAUSS, 2009, p. 450) em relação aos tipos de conflitos que podem ser lá processados e julgados (NUÑEZ, 2015). Trata-se, ainda, de um procedimento "bifásico", conforme define a classificação nativa.

O presente artigo está dividido em três partes, além desta introdução e da conclusão: (i) descrição do caso de Maria da Silva, a "cracuda"; (ii) apresentação do caso "Bruno Eusébio"; e (iii) apontamentos sobre as classificações que recaem sobre vítimas, réus e suas mortes, em razão dos valores morais e das moralidades dos agentes.

\section{“COM DEFUNTO RUIM NÃO SE GASTA VELA!": O CASO DE MARIA DA SILVA}

Maria da Silva foi classificada pelos sucessivos agentes que administraram institucionalmente a sua morte como "cracuda", "drogada", "bêbada" e "ladra", desde o tratamento de sua morte na fase policial até a realização do Júri. No dia

\footnotetext{
Essa característica do sistema de justiça criminal, isto é, a existência de diferentes procedimentos para julgar o mesmo evento de morte, tendo por norte a intenção do autor dos fatos - o réu - e não os fatos, explicita a "sensibilidade jurídica" (GEERTZ, 2007) brasileira, identificada como inquisitorial, como há muito vem sendo apontado por Kant de Lima (2010).

9 É bifásico porque se divide na fase anterior e posterior à pronúncia, que é a decisão do juiz quanto à "competência" do júri para julgar o caso. Isto é, nesta primeira fase, o juiz avalia se o caso será ou não levado à julgamento pelos jurados. Na seguinte, caso o réu seja pronunciado, será submetido à julgamento por sete jurados numa sessão especial para esse fim.
} 
29 de agosto de 2010, foi encontrada morta em Guaratiba, zona oeste do Rio de Janeiro. O corpo de Maria foi “alvejado por disparos de arma de fogo". Já no documento que "instaurou" o inquérito, o fato vinha assim relatado: "encontro de um cadáver, morto por dois tiros", seguido da afirmação de que "a investigação preliminar apurou que a vítima era usuária de drogas e cometia pequenos delitos para sustentar seu vício, inclusive tendo sido autuada por furto".

Depois, foi juntado ao inquérito o "Relatório de Local de Homicídio". Neste documento, após a descrição do cadáver, como "do sexo feminino, de cor negra, cabelos pretos, porte físico magro, olhos de cor preta e aparentando ter quarenta anos", vinha a frase "segundo apurado inicialmente, a vítima era usuária de drogas, além de praticar pequenos delitos na região, com o intuito de angariar dinheiro para sustentar seu vício”. Na polícia, dois policiais militares e a ex-cunhada da vítima foram ouvidos. Nenhum deles presenciou a morte de Maria, isto é, o fato que levou ao seu óbito. No entanto, as impressões da ex-cunhada sobre ela estão na investigação: "era viciada em drogas e frequentava bocas de fumo".

O procedimento seguiu o seu percurso e nele foram inseridos mais documentos ${ }^{10}$. Por exemplo, o laudo de exame de corpo de delito, produzido pelos peritos do Instituto Médico Legal (IML) ${ }^{11}$, que confirmava a morte em razão dos disparos de arma de fogo e identificava a presença de três papelotes "contendo resquícios de pó branco" junto às roupas da vítima. Ainda, foi juntado ao procedimento o "relatório de vida pregressa" e o "boletim individual" dela. Também havia informações sobre sua escolaridade, "1º grau completo",

\footnotetext{
${ }_{10}$ Diversos são os documentos que podem vir a ser inseridos durante a produção cartorial de um inquérito policial. Por exemplo, o exame do corpo de delito, quando a vítima sofreu ferimentos mas continua viva; o laudo de necropsia, quando morreu, como no caso de Maria. Ainda, há os registros das declarações das testemunhas, bem como os termos do que foi falado por quem virá a ser indiciado pelo delegado. Todos esses papéis vão formando o "corpo" do inquérito. No caso de Maria, havia igualmente o "laudo de exame em local de morte violenta", que trazia fotos do lugar onde o cadáver foi encontrado, bem como do próprio cadáver, e dizia que a mulher foi alvejada à curta distância, o que levava o perito a constatar que estava o "agente ao lado esquerdo da vítima".

${ }_{11}$ Para mais informações sobre a transformação dos corpos mortos em documentos por meio do trabalho dos agentes do instituto médico legal do Rio de Janeiro e os pormenores desse processo (cf. MEDEIROS, 2016). Ainda, o artigo de Veiga (2015) traz uma descrição pormenorizada do que é um laudo policial e esmiúça os documentos presentes em um processo, de modo a pensar também em sua "vida institucional" e o "tempo dos papéis e nos papéis".
} 
de religião "evangélica" e sua profissão, "diarista". O "vulgo" atribuído a ela era "Naco" e teria como vícios "álcool, tabaco e cocaína". Como antecedente criminal, imputavam um "furto no interior de residência", sem indicação da data que tal crime teria ocorrido e se havia sido julgado pela justiça ${ }^{12}$. Assim, a menção dos peritos ao "pó", bem como as demais informações sobre seu apelido e o uso de substâncias entorpecentes formava uma representação sobre a vítima como usuária de drogas, o que parecia fundamental na elucidação do crime.

Quando os policiais pesquisaram possíveis dados sobre a "testemunha" inicialmente ouvida, a ex-cunhada de Maria ${ }^{13}$, constataram que ela teria sido vítima do "furto no interior de residência" ocorrido em 2004, "no qual figurava como autora Maria da Silva”. Mesmo sabendo dessa informação, consideraram seu depoimento como válido e prosseguiram com as investigações. A segunda testemunha ouvida pelos policiais foi a filha da vítima. Suas declarações apontavam para o fato de que a mãe era "usuária de drogas, bebia e gostava muito de forró". "Nos fins de semana estava sempre nos bares da região do Cantagalo e não trabalhava, mas fazia faxinas ocasionalmente". O seu companheiro trabalhava na Comlurb ${ }^{14}$ de Campo Grande, na parte de reciclagem de garrafas pet.

Em seguida, os inspetores ouviram, pela terceira vez, a ex-cunhada da vítima. Além de ressaltar que Maria era usuária de drogas e álcool, disse que a falecida tinha nove filhos "com pais diferentes" e que nenhum deles morava com ela. Informou que criava uma das filhas da vítima "desde os nove meses". Mencionou também em suas declarações o "furto no interior de residência", segundo o qual Maria, "há aproximadamente três anos, furtou a casa da declarante, subtraindo $\mathrm{R} \$ 300,00$ além de objetos pessoais e vendeu os objetos pessoais na boca de fumo".

Depois, os policiais ouviram o companheiro da vítima. Ele afirmou que Maria era usuária de drogas e álcool, costumava passar as noites fora de casa e trabalhava como faxineira na residência de outra mulher, também usuária de

\footnotetext{
${ }_{12}$ Diz o artigo $5^{\circ}$ da Constituição Federal de 1988, que lista os "direitos e deveres individuais e coletivos" no inciso LVII, que "ninguém será considerado culpado até o trânsito em julgado de sentença penal condenatória”. No entanto, os registros policiais são usados, na prática (KANT DE LIMA, 1995), como "antecedentes criminais" para formar as impressões dos agentes do campo sobre aqueles que estão sendo avaliados. No caso, a vítima.

13 Nos documentos da polícia, são citados os seguintes sistemas: ICA/SEI; Medusa/ Polinter; Sistema S.I.P.; e Roweb.

${ }^{14}$ Companhia Municipal de Limpeza Urbana.
} 
drogas. Segundo ele, no dia dos fatos, o casal ficou bebendo até às 17 horas. Depois ele voltou para casa e a vítima saiu "muito alcoolizada". E que, antes do homicídio, teria sido "ameaçada", mas não apontou por parte de quem estaria sofrendo tais ameaças. O inquérito ficou parado por sete meses, entre dezembro de 2010 e julho de 2011, momento no qual o delegado registrou em um documento que gostaria de ouvir as duas mulheres apontadas como amigas da vítima.

As investigações foram retomadas no ano seguinte, quase doze meses depois do homicídio de Maria, quando a filha de uma dessas mulheres, referidas como amigas da vítima, foi até a delegacia prestar declarações. Segundo ela, tanto sua mãe quanto Maria haviam sido mortas por "Jorge do Posto", miliciano da região, pois ambas eram usuárias de drogas e bebiam nos bares da localidade. Assim, a vítima "sabia demais" a respeito das atividades ilícitas levadas a cabo por tal homem, já que frequentava os mesmos bares que ele. $\mathrm{O}$ miliciano teria dito que iria "limpar o Cantagalo". Os investigadores então reputaram a fala dessa testemunha e as informações de que "Jorge do Posto" era "chefe" da milícia ${ }^{15}$ do local. Ainda registraram no documento que ela, desde que soube das "execuções", mudou-se da região, pois sofreu ameaças de morte. A testemunha afirmou, por fim, que a filha de Maria sabia que "Jorge do Posto" havia matado sua mãe, mas não queria dizer isso na Polícia por medo dos “milicianos".

Com esse último depoimento, seguido do reconhecimento que a então declarante fez de "Jorge do Posto", os policiais encerraram o inquérito ${ }^{16}$. O "relatório", peça final do procedimento policial, destacava as dificuldades de investigar esse tipo de crime:

É importante que se destaque a dificuldade na condução das investigações de homicídios praticados por organizações criminosas (milícias).

\footnotetext{
${ }_{15}$ Vide, dentre outras pesquisas sobre milícias: "No sapatinho": a evolução das milícias no Rio de Janeiro (2008-2011)" " "Segurança, Tráfico e Milícias no Rio de Janeiro", no LEV-UERJ. Além deles, Michel Misse (NECVU/UFRJ) coordenou projeto intitulado "Mercados ilegais, mercadorias políticas e organização local do crime no Rio de Janeiro" entre os anos de 2009 e 2015, que também buscou investigar o fenômeno.

${ }^{16}$ Antes do encerramento do inquérito, os policiais tomaram "provas emprestadas" de outras investigações para nele inserir declarações ligando o morto ao contexto territorial onde a morte aconteceu (MEDEIROS, 2018). Trazendo, assim, testemunhos relacionados com outros fatos que tinham "Jorge do Posto" apontado como autor. O inquérito da morte de Maria da Silva foi aditado em 6 de dezembro de 2011, para inserir o acusado em tal condição.
} 
As relações de poder que se estabelecem nas comunidades em que elas atuam, calcadas em um verdadeiro terror, fazem com que as testemunhas, geralmente moradores da localidade, tenham medo de dar qualquer informação a respeito dos crimes. As provas testemunhais ficam prejudicadas em função da ameaça engendrada pelos milicianos que ali atuam (Relatório do Inquérito Policial).

O caso foi levado à Justiça e, recebida a denúncia, houve audiências de instrução e julgamento. Nelas, compareceram quatro testemunhas que, como esperam os agentes do judiciário, reafirmaram o que foi dito em sede policial. $\mathrm{O}$ réu ficou em silêncio durante a fase de instrução, técnica adotada pelos defensores para não ocorrer contradição entre o que é dito na primeira fase e o que pode vir a ser falado na sessão plenária. Ele foi pronunciado em 20 de março de $2013^{17}$.

A sessão de julgamento que assisti ocorreu em 29 de junho de 2015. Nesse dia, as testemunhas compareceram para depor, mas foram dispensadas. Logo que cheguei ao plenário, Fernando, o defensor que atuaria naquele caso, prontamente me informou: “esse júri vai ser rápido". Sua fala explicitando tal previsão sinalizava que ele havia previamente conversado com Pablo, o Promotor de Justiça, oportunidade em que fecharam o "acordo"18. Minha intuição foi confirmada depois, como ambos me explicariam em seguida.

Nos “júris de acordo”, como aquele, as falas durante as sustentações orais podem ser usadas para "ensinar" os jurados sobre o funcionamento dos processos e procedimentos e, sobretudo, o que se espera deles, além de abordar os sentidos das atividades profissionais dos agentes. Nesse dia, o promotor, além

\footnotetext{
17 Trecho da sentença de pronúncia dizia que: "o delito acima referido foi praticado por motivo torpe, em atividade típica de grupo de extermínio (vigilantismo), havendo o denunciado resolvido justiçar a vítima -assumindo as funções de juiz, júri e executor na comunidade - pelo fato de ela não se adequar ao comportamento social exigido pela organização criminosa por ele comandada, eis que consumia regularmente substâncias entorpecentes. $\mathrm{O}$ delito foi perpetrado, ainda, para assegurar a impunidade de vários outros crimes de homicídio cometidos pelo denunciado, haja vista que a vítima, sempre que ingeria bebidas alcoólicas em estabelecimentos comerciais variados, relatava para os presentes quais pessoas o acusado havia assassinado na localidade.

18 Raras vezes pude acompanhar a realização dos acordos, pois eles são feitos entre acusação e defesa, antes da sessão, e até mesmo por telefone, por meio de ligações ou da troca de mensagens, via Whatsapp. No entanto, seja por comentários dos agentes, ou por certos indícios durante as audiências, como a redução do tempo dos julgamentos, era possível perceber a existência ou não dos mesmos. No caso, as testemunhas foram dispensadas e o réu ficou em silêncio. Por esse motivo, passaram diretamente às sustentações orais, iniciadas pela fala do promotor. Essa forma de proceder indica a realização de um "acordo".
} 
de fazer a fala acusatória, aproveitou para elogiar o trabalho da Defensoria Pública e desqualificar os advogados, explicitando quem integra a família judicial (NUÑEZ, 2018) como uma rede de relações (KANT DE LIMA, 1994) que se estabelece no contexto do júri.

Quando o promotor passou a sustentar a acusação, disse aos jurados que pediria a absolvição por "absoluta falta de provas". Ou seja, que seu pedido não se devia ao fato do acusado ser "boa pessoa, trabalhador", mas porque "nesse processo a prova não traz elemento de certeza". Durante sua argumentação, reforçou dois aspectos em especial: a personalidade da vítima e de seu companheiro e a inexistência de provas. A vítima, dizia ele, "é difícil acusar que ela apenas bebia, olha bem essa foto, é a foto que demonstra uma usuária de drogas e esse tipo de pessoa não é aceita onde tem grupos de extermínio [...] mas não sabemos quem pegou essa Maria, se ela tinha dívidas com traficante". Encerrou dizendo que "[...] a vítima nesse caso não me inspira credibilidade nenhuma, eu não sei se ela tinha dívida com traficante, se ela brigou na rua, se foi a milícia e o vigilantismo [...] eu só sei que a vítima foi pega por um carro e depois desovada [...]". Sobre o companheiro da mulher, afirmava: “esposo da vítima que tem cara de quem usa drogas também” e assim desqualificava o depoimento do homem.

Quanto às provas, reputava sua má qualidade às investigações e à dificuldade de produzi-las em áreas de milícia. Dizia que "o acusado também não é flor que se cheire, já respondeu a vários processos, mas esse não foi bem investigado e os autos não trazem certeza de que ele pegou essa senhora e a matou". Ao final, disse ao réu: "alerto o senhor [nome do acusado] que acima dos homens há a justiça divina, tarda, mas não falha”. Por fim, elogiou Fernando, o defensor, com quem fazia a sessão no dia, como um "defensor tem um nome a zelar", pois está "sempre" no Júri, em contraste com os advogados. Em seguida, encerrou a sua fala, que durou pouco mais de meia hora.

A palavra foi passada para Fernando, que abriu seu discurso retribuindo o elogio ao promotor, "pois ele sabe distinguir a função de acusador e aquela que acusa sem humilhar". Seu comentário pode ser pensado como um enaltecimento tanto em relação à forma como o promotor conduz as sustentações quanto à 
maneira como procede durante os acordos. Em seguida, emendou na argumentação sobre a ausência de provas, também culpabilizando a vítima pela sua morte:

Aqui não existe nenhum indício de autoria, o Doutor Antônio [o Juiz] não teria sequer pronunciado [...] pelo perfil da vítima, podemos perceber que ela se envolvia em problemas [...] e não tem nem indício de que o Jorge do Posto integrava a milícia, os senhores decidirão com o que foi produzido e no processo não foi produzido nada! O que percebemos era que a vítima era uma pessoa de desafetos. Estamos aqui para decidir a morte da senhora Maria, que não existe nada [...] haverá situações em dúvida, mas aqui não há nada [...] e a vítima o que fez? Por ingratidão? [...] roubou a amiga! Essa é a vítima! (Notas do Caderno de Campo).

A defesa terminou sua fala em meia hora usando, portanto, somente um terço do tempo que dispunha ${ }^{19}$. Há uma dimensão quanto ao subaproveitamento do tempo disponível para a fala, que é reflexo da baixa relevância atribuída ao caso por parte dos agentes. Ademais, diante de um pedido de absolvição por parte da acusação, o discurso do defensor acaba esvaziado, pois não há o que sustentar em contraposição. Fernando precisava apenas concordar com o pedido do promotor. Assim, os debates foram encerrados por volta das 16:16 horas, bastante cedo, quando comparado com os julgamentos de "briga" ou as "bolas divididas".

Após a votação que absolveu o acusado, enquanto aguardávamos pelo juiz que elaborava a sentença, pude conversar, na sala secreta, com Pablo e Fernando, respectivamente, o promotor e o defensor do caso. O primeiro, quando indaguei sobre as provas, se lhe pareciam de fato ruins, nada falou sobre elas. No entanto, sorrindo, limitou-se a dizer que “não se gasta vela com defunto barato!”. Em seguida, encaminhando-se para voltar ao plenário, afirmou novamente sorrindo: “é, às vezes a gente tem que avaliar!". Foi, por fim, que Fernando voltou-se para mim ao final do diálogo e repetiu uma frase que havia enunciado durante outro julgamento: "não dá pra viver naquela tensão".

\footnotetext{
${ }^{19}$ De acordo com o art. 477 do Código de Processo Penal, cada uma das partes conta com uma hora e meia para fazer suas argumentações e, na réplica e tréplica, se houver, com mais uma hora.
} 
Percebi, nesse diálogo, que duas dimensões balizavam o trabalho dos agentes naquele dia. A primeira, relacionada ao valor que eles atribuíam à vítima. Nesse caso, ela era medida por ser "cracuda" e "alcoólatra", de modo que não fazia, para eles, muita diferença a condenação do réu. A outra foi explicitada em seguida, quando ambos pontuaram as escolhas que precisavam fazer ao longo do desempenho de suas funções. Os dois chamavam atenção para os meios por eles encontrados para fazer com que o trabalho dos agentes se tornasse menos desgastante, em consonância com o que enunciou o defensor. As duas manifestações, tanto da acusação quanto da defesa, não estavam relacionadas com os processos, com as provas produzidas e inseridas nos "autos" e, muito menos, com os conflitos que desencadearam tais mortes, mas com a avaliação que faziam da vítima e, igualmente, com a energia a ser dispensada por eles para a execução do seu trabalho.

Essa forma de desempenhar o serviço público, não como à serviço da sociedade, mas como um favor oferecido aos que dele fazem uso, assemelha-se àquela identificada por Miranda (2000) no âmbito dos registros públicos e cartórios judiciais. Os servidores não decidem sobre os acordos a partir do interesse das partes, mas com base no seu tempo e na redução do seu traba$\mathrm{lho}^{20}$. Da mesma maneira, afigura-se como uma forma de lidar com a burocracia que não é a "burocracia weberiana, baseada na igualdade perante à lei" (MIRANDA, 2000, p. 67), mas no tratamento diferenciado dos processos, orientado pelas moralidades situacionais (EILBAUM, 2012) que o caso e seus personagens acionavam nos agentes.

Sobre a construção das vítimas, o caso de Maria mostra como tal categoria é engendrada por toda uma lógica social que também explicita valores. Isto é, por consistir em uma figura contemporânea (SARTI, 2011) e, justamente por isso, associada aos fenômenos da violência e do sofrimento ${ }^{21}$, não é atribuída a

\footnotetext{
${ }^{20}$ No mesmo sentido, a pesquisa de Brito (2017) demonstra como os funcionários do cartório consideram o "tempo do cartório" como à parte de outros "tempos" processuais legais, como sendo "criados no cartório judicial”, baseados no domínio das práticas pelos serventuários, que detêm o poder e por isso controlam o tempo (2017, p. 112).

${ }^{21}$ Inclusive no contexto da rede de saúde pública, pesquisas mostram os obstáculos ao atendimento para homens vítimas de violência sexual, já que as equipes especializadas em tais atividades são compostas por ginecologistas e obstetras (SARTI, 2009).
} 
qualquer pessoa pelos agentes do estado. Embora do ponto de vista formal e jurídico a "cracuda" fosse vítima, pois morreu, do ponto de vista moral, isto é, de como os agentes a viam, ela não se encaixava nesse lugar. A gramática do contexto do Júri não dava à Maria legitimação moral para que fosse enquadrada no papel de vítima, o que também levou ao pedido de absolvição por parte do MP.

\section{“HOJE É DIFERENTE!": O CASO BRUNO EUSÉBIO}

Segundo consta na denúncia, Bruno Eusébio dos Santos, estudante do curso de mestrado do Instituto Nacional de Matemática Pura e Aplicada (Impa), matou José Leandro, seu colega de curso e de quarto, a pauladas e facadas. Dizia o processo que, antes do crime, Bruno vinha enfrentando "problemas" nas disciplinas que cursava e, por isso, teria buscado ajuda psiquiátrica. O médico que o atendeu receitou remédios de uso controlado os quais, na noite do crime, ele ingeriu junto com bebida alcoólica, levando a um estado de "grave embriaguez". Em razão disso, dizia não se recordar do que aconteceu na noite dos fatos. O crime foi cometido no quarto que ambos dividiam, dentro de uma casa semelhante à uma pensão, onde moram apenas estudantes do Impa. À época dos fatos, houve grande repercussão na mídia ${ }^{22}$ com a respectiva edição de notícias em jornais impressos e televisivos.

Quando cheguei à sessão de julgamento, por volta das 13h30, fui procurar Daniel, o defensor que atuaria no dia. Ele estava na carceragem conversando com o réu, seu "assistido". A convite dele, entrei no recinto para acompanhar o atendimento, que precedeu ao início da sessão. Atrás das grades estava Bruno, um rapaz alto e gordo, vestindo camiseta branca, bermuda jeans e chinelos da marca havaianas. Algemado, enquanto comia um pedaço de pão, ele caminhou até nosso encontro e parou diante de nós, permanecendo dentro da cela, separado de nós pelas grades. O réu parecia não entender muito bem

${ }_{22}$ Vide, por exemplo, as reportagens veiculadas nos sites de notícias da cidade do Rio de Janeiro: Thum (2012) e Estudante... (2012). 
o que o defensor falava, embora respondesse "sim" ou "não" às perguntas que lhe eram feitas. Disse não lembrar do que aconteceu "naquela noite", observação que repetia desde o seu depoimento em sede policial.

Retornei ao plenário na companhia de Daniel, após a breve conversa. Em seguida, Pablo, o mesmo promotor que atuou no caso da "cracuda", e Marcos, o juiz, adentraram no recinto e mandaram chamar os jurados e o acusado para dar início à sessão. Havia quatro testemunhas presentes, mas duas foram dispensadas. No entanto, diferentemente do caso anterior, nesse julgamento duas testemunhas foram ouvidas. A primeira era um jovem estudante do Impa, colega da vítima e do réu na pós-graduação. Ao longo de seu depoimento, sempre muito tranquilo, disse que havia cursado a graduação na mesma faculdade que a vítima, na Universidade Federal do Ceará, estado em que ambos haviam nascido. Segundo seu relato, foram apresentados um ao outro ainda antes da realização do curso de mestrado no Impa, demonstrando, com isso, vínculos prévios que não chamaram atenção do magistrado para esta condição, como em geral ele fazia em outros casos que despertavam desconfiança quanto aos "personagens".

Continuou, então, indagando sobre o curso de pós-graduação, as acomodações que dividiam, o valor da bolsa de estudos que recebiam, entre outros pontos. Como, além de ser amigo de José Leandro, esta testemunha havia compartilhado quarto com Bruno antes do acontecido, Marcos a questionou sobre o motivo de sua mudança de acomodação. A partir dessa pergunta, o foco do depoimento passou a ser o "comportamento do réu": o magistrado indagou se ele bebia, se era uma pessoa "aberta" ou "fechada", se tinha um "comportamento normal", se "viu ele praticar algum ato que fosse incompatível com os padrões de normalidade?". Também questionou sobre a personalidade da vítima que, pelo amigo, foi caracterizado como "divertido, calmo e tranquilo". Indagou ainda sobre o "futuro" de José Leandro. O colega lhe respondeu que a vítima pretendia fazer "doutorado nos Estados Unidos". E continuou:

Juiz - Bem, o senhor já falou dos personagens, vamos falar dos fatos. Testemunha - Quando eu fui fazer depoimento, me perguntaram umas 
coisas estranhas, se [o réu] sofria bullying etc.

J - Isso eu também tenho interesse em saber.

$\mathrm{T}-[\ldots]$ teve vários boatos. Algumas pessoas falavam que ele não estava bem nas provas, alguma pressão, alguma coisa assim.

J - O José Leandro tinha um bom desempenho?

T - Tinha, ele estudava muito [...] tinha 22 ou 21 anos, não tenho certeza

(Notas do Caderno de Campo).

Encerradas as perguntas do juiz, a palavra foi passada para acusação e, em seguida, para a defesa. Ambos focaram suas indagações no comportamento de Bruno, se ele era "retraído" e "introspectivo" e se "bebia". A testemunha respondeu que ele raramente bebia e que as pessoas perguntavam se o réu era "maluco".

Defensor - O senhor disse que viu o Bruno bebendo uma cervejinha.

O senhor já o viu alcoolizado?

Testemunha - Nunca.

D - Mas quando vocês iam sair, ele saia?

T - Não. A gente achava normal, que ele não gostava de sair.

[...]

$\mathrm{D}$ - O senhor se recorda se ele tomava algum remédio?

$\mathrm{T}$ - Ele tinha lá uns remédios no quarto dele lá.

Encerrada a oitiva dessa testemunha, passaram para a seguinte: $\mathrm{o}$ caseiro da residência onde o crime ocorreu, que também demonstrava tranquilidade. Marcos novamente iniciou as perguntas, sem fazer nenhuma referência ao "dever inafastável da verdade" e sem questionar sua relação com o acusado e a vítima, diferença do que fazia com outras pessoas que iam testemunhar, ficando explícito que o caseiro, assim como o jovem estudante que figurou como testemunha antes dele, não despertavam desconfiança de sua parte. O modo descontraído como iniciou sua fala demonstrava ausência de tensão:

Juiz - Percebo um sotaque?

Testemunha - Sim, cearense.

J - Cearense gosta de matemática? E de fazer rir?

$\mathrm{T}$ - Pois é. 
J - Sendo cearense evidentemente veio para fazer o curso?

T - Não, eu trabalho na casa há dois anos e meio.

J - Então é uma coincidência. O senhor conhecia tanto o acusado quanto a vítima, então. O senhor mora lá? Trabalha lá?

$\mathrm{T}$ - Meu horário é das 9 às 17 horas. A cozinha todo mundo usa lá, ele foi fazer o café e encontrou o Bruno no chão e o fogão arrastado. Eu vi o Bruno dormindo, num sono muito profundo. Ele não respondia. $\mathrm{E}$ aí eu falei, vamos falar com o José Leandro. Bati e ninguém respondia. J - E a essa altura esse aí [referindo-se ao réu] dormindo?

$\mathrm{T}$ - Ele tava dormindo, roncando.

J - Cheirava? Tinha cheiro de bebida? Tinha vômito.

T - Era um cheiro forte, eu não vi cheiro de bebida, de comida azeda (Notas do Caderno de Campo).

O juiz deu continuidade ao depoimento. Questionou sobre o formato em que se organizava a residência e as acomodações do local, o número de habitantes, se compartilhavam os quartos, como era o uso da cozinha, a rotina dos estudantes durante a semana e também nos dias de folga. Perguntou ao caseiro especialmente sobre as personalidades da vítima e do acusado e, depois, sobre o dia dos fatos.

Juiz - E o José Leandro? Como era o José Leandro?

Testemunha - Eu ficava conversando com ele, ele falava de futebol.

[...]

J - O José Leandro fez alguma queixa dele [do réu]?

$\mathrm{T}$ - Nunca, até um dia eu perguntei pra ele como era morar com uma pessoa que não dá nem boa noite, ele disse que não tinha problema não.

Após encerrar suas perguntas, passou a palavra para Pablo e Daniel. Novamente, ambos fizeram indagações focadas na "normalidade" ou "anormalidade" do comportamento do acusado e sobre a ocorrência de algum "surto" por parte dele. Em seguida, foi encerrada a oitiva das testemunhas e o réu não foi interrogado porque, por orientação do defensor, ficou em silêncio.

Houve então um intervalo para almoço dos jurados e, em seguida, iniciou-se a sustentação oral em plenário. Pablo, depois de cumprimentar os presentes, disse: 
Hoje o caso é simples, eu não vou ficar falando muito aqui por que não tem muito o que ficar falando [...]. Até hoje não se sabe por que ele teria feito isso. Ele chegou a prestar depoimento, tava sem dormir, tirando notas baixas e quem pagou o pato foi a vítima. O IMPA, todos devem conhecer, e lá tem até uma biblioteca bem grande, em que todos estudam. A materialidade não tem dúvida, a vítima morreu, o acusado assumiu a autoria. A questão é em torno da inimputabilidade, semi-imputabilidade, quando o acusado merece redução de pena, pela perturbação da saúde mental. Aqui no Brasil adotamos o critério biopsicológico. Bio, de biológico, quem tem mais de dezoito anos, e psicológico, entender o caráter do ilícito e ter capacidade de se auto determinar [...]. [Promotor pega o processo e mostra para os jurados] [...] essa daqui é a vítima, para os senhores terem uma ideia de que a vítima está toda ensanguentada. Foi esfaqueada dormindo, várias vezes, e mais uma vida se perdeu aí. A discussão hoje, se houver, deve ficar nisso. Ele [réu] era ou não capaz de responder pelos atos. Então, quem vai dizer isso é uma pessoa perita, que constatou isso, no laudo de insanidade mental, ele não é inteiramente capaz de controlar os seus atos. Isso diminui a pena de 1 a 2/3. E isso que vai ficar a critério do magistrado. Então o pedido do MP é exatamente esse. Nos autos já existe a confissão do acusado em sede policial. [...]. No $3^{\circ}$ quesito, o MP espera que os senhores votem não, não vamos absolver o acusado, que matou outro, que eram colegas de quarto. [...] o MP pede que os senhores reconheçam a semi-imputabilidade do réu (Notas do Caderno de Campo).

A fala do promotor foi bastante breve, durou em torno de 35 minutos. Ele sustentou a condenação, porém com o reconhecimento da "inimputabilidade"23 de Bruno, reduzindo assim a medida da pena e a forma de seu cumprimento. Além disso, sua alocução me pareceu bastante ascética, pois não houve variação na entonação de voz, nem gritos ou qualquer demonstração de emoção, que são indicadores da existência de "briga" com o defensor. Aos meus olhos, não havia "carga", categoria nativa que meus interlocutores usavam para tratar dos processos cuja energia empregada por eles, fosse intelectual ou de oratória, era

${ }^{23}$ A "inimputabilidade" é uma categoria nativa do campo do direito. Refere-se à capacidade que o praticante de ato definido como crime tem ou não de compreender o que está fazendo e, assim, poder determinar se será ou não legalmente punido. $\mathrm{O}$ art. 26 do Código Penal determina quem são inimputáveis, dizendo que: "é isento de pena o agente que, por doença mental ou desenvolvimento mental incompleto ou retardado, era, ao tempo da ação ou da omissão, inteiramente incapaz de entender o caráter ilícito do fato ou de determinar-se de acordo com esse entendimento". Além destes, os menores de dezoito anos também o são. 
considerada maior. "Fazer carga", para eles, é usar de todos os recursos possíveis para sustentar a tese, seja da acusação, seja da defesa. Em seguida, o juiz passou a palavra a Daniel que, após as saudações de costume (ao juiz, promotor, jurados), cumprimentou os familiares da vítima e do réu, anunciando porque aquele era um julgamento "diferente" para ele. Disse:

não posso deixar de citar quatro pessoas que naquela noite se ligam depois dos fatos, porque hoje é diferente! Julgamos aqui traficantes, policiais, criminosos, abortos, infanticídios, são crimes de uma violência diária. Hoje temos a infelicidade de anunciar um julgamento sem essa intenção. Os pais do Bruno, e digo aos pais de José Leandro que infelizmente esse fato aconteceu aos dois jovens. Dedico toda sorte aos pais de Bruno e aos pais de José Leandro, depois de uma tragédia como essa. $O$ faço porque já estive fora em meus estudos e sentia quase que diariamente aquela sensação de preocupação dos meus pais, o mesmo acontecia aos pais desses jovens e infelizmente no dia 25 de outubro não tinha uma motivação objetiva para que essa tragédia acontecesse. Meu dever profissional demanda que eu atue na defesa, mas eu não posso deixar de falar aos familiares da vítima (Notas do Caderno de Campo).

A defesa não negou o fato, não criou uma tese sobre o que teria ocorrido. Ao contrário, expressamente reconheceu a existência de materialidade e autoria. Mas focou nas pessoas envolvidas no crime. Segundo ele:

não estamos falando de bandidos, não estamos falando de criminosos, estamos falando de dois jovens. Bruno não tinha essa liberdade de escolha. A questão é essa aos julgadores. Precisa Bruno Eusébio estar preso? Estar encarcerado? Se Bruno Eusébio merece estar encarcerado estaríamos trocando um futuro pela sua conduta [...] A atividade debiloide não se instalou no dia 25 de outubro, no dia 26. Ele sozinho procurou uma psiquiatra. E determinou que Bruno tomasse alguns remédios. Algo já vinha acontecendo antes. Há um relato de que ele havia faltado uma prova no curso. Ou seja, não foi um dia. Já havia um precedente histórico dessas atividades debiloides. Em alguns casos sabemos que há responsabilidade da vítima, mas não é esse o caso. Eu acompanho esse processo, eu atendo os familiares, desde a prisão do Bruno eu imaginei que houvesse um bullying, mas eu não te- 
nho esse tipo de sentimento [...]. Bruno não tinha a intenção de matar José Leandro, temos que pensar para que levamos a decisão desse processo. Bruno precisa de uma pena? De um castigo? Ou precisa de internação? O fez com maldade o ato? Não posso em hipótese nenhuma compará-lo ao marido que mata a mulher por ciúmes, a um traficante. [...] E diz o perito: necessita submeter-se a tratamento psiquiátrico. O que nós, a sociedade, precisamos decidir é o que o Bruno merece. A família de Bruno, do interior do Nordeste, assim como a de José Leandro. Os atos precisam ter consequências, punição a Bruno não resolve muito. É dizer que nessa hipótese, que pode ser aplicar uma pena privativa de liberdade ou aplicando o que o direito quer. O que a defesa dele aponta é que ele seja condenado ao que ele merece (Notas do Caderno de Campo).

Ao final de sua fala, Daniel repassou um a um os quesitos ${ }^{24}$ que, posteriormente, foram apresentados aos jurados na sala secreta, e encerrou seu discurso. A sustentação durou em torno de 40 minutos. Se excluídas as saudações, que se estenderam por 25 minutos, significa que, sobre o caso, falou menos de vinte. Havia, entre acusação e defesa, uma representação compartilhada sobre o destino que merecia aquele réu, pois o caso não envolvia "bandidos", mas, sim, configurava-se como "uma tragédia”. Havia convergência moral e por isso não fizeram "carga", pois os pedidos das duas partes eram no sentido da condenação, com a redução da pena, configurando-se no mesmo resultado.

\footnotetext{
${ }^{24}$ Ao contrário do Júri norte-americano recorrentemente retratado em filmes e séries de televisão, no modelo brasileiro não há discussão livre do caso e da sentença por parte do conselho, que decide de maneira unânime. Há, sim, uma votação de "quesitos" que devem seguir a forma delimitada pela lei, isto é, em conformidade com o Código de Processo Penal, no arts. 482 e seguintes. Essas perguntas, respondidas secretamente pelos jurados por meio das cédulas contendo "sim" ou "não", devem ser redigidas "em proposições afirmativas, simples e distintas", de modo que cada uma possa ser respondida com "suficiente clareza e necessária precisão". E, para as elaborar, o juiz "levará em conta os termos da pronúncia ou das decisões posteriores que julgaram admissível a acusação, do interrogatório e das alegações das partes". Seguem, também, uma ordem, indagando inicialmente sobre "I - a materialidade do fato; II - a autoria ou participação; III - se o acusado deve ser absolvido; IV - se existe causa de diminuição de pena alegada pela defesa; $\mathrm{V}$ - se existe circunstância qualificadora ou causa de aumento de pena reconhecidas na pronúncia ou em decisões posteriores que julgaram admissível a acusação. A votação é encerrada por maioria, isto é, constatado quatro votos para "sim" ou "não", as demais cédulas nem sequer são abertas, pois o magistrado presume o seu resultado. Todos esses dispositivos são fruto de uma reforma pelo qual o processo do júri passou no ano de 2008. Importante dizer que, caso o réu seja condenado, o juiz elabora mais quesitos sobre possíveis causas de aumento ou diminuição de pena.
} 
Votada a condenação na sala secreta, com a decisão dos jurados pela semi-imputabilidade do acusado, o juiz confeccionou a sentença e a leu, diante de todos, que dizia:

Acolhem a inimputabilidade relativa. Não havendo dissidência na sala secreta, optamos por esse veredito. Dosimetria da pena: hoje, pelo dizer do ilustríssimo promotor de justiça, uso o mito da caixa de pandora. Esse mito se passa na Grécia antiga, não conseguimos aceitar que um semelhante a nós tenha tamanha crueldade $[\ldots]$ a semi-imputabilidade não exclui a sua condenação $[. .$.$] um crime bárbaro, realizado$ por uma pessoa comum, nos coloca diante da sensação punitiva [...] as justificativas são tão banais quanto perturbadoras, então usamos a palavra loucura. E esta é a questão que deve ser colocada em pauta. [...] o acusado demonstra plena capacidade intelectiva, do contrário não faria bacharelado em matemática e posterior pós-graduação. Vontade e pragmatismo perfeitamente preservados. Trágico, induvidosamente trágico. [...] A vítima era um jovem feliz, e isso tudo se passa em [nome da cidade do Nordeste onde a vítima nasceu], tudo lhe foi subtraído, a vida pegou-lhe insone, morreu enquanto dormia. [...] precisamos de uma justiça viva, equilibrada e capaz de satisfazer as expectativas do bem comum. Aplico a pena de 12 anos, reduzida de $1 / 3$ que resulta em oito anos de regime fechado (Notas do Caderno de Campo).

O julgamento durou três horas, descontados os intervalos para alimentação. A rapidez na realização do ato explicita a inexistência de "briga" e, por outro lado, um "acordo" entre defensor e promotor sobre o que sustentar em seus discursos e como fazê-lo para, ao final, "condenar" o acusado. Nesse julgamento, os agentes não expressaram, quer para mim, quer para os jurados, que de fato tenham realizado um acordo prévio. Até mesmo porque nos debates públicos, isto é, para o conselho de sentença, eles raramente expunham o acordo. $\mathrm{Na}$ maior parte das vezes, omitiam o que havia sido acertado. No entanto, o tempo e as circunstâncias do julgamento, assim como a sua duração, eram elementos que apontavam para isso, bem como as respectivas falas, que continham os mesmos pedidos e argumentos.

As perguntas sobre o comportamento "anormal" do réu demonstram uma hierarquização entre as pessoas que são consideradas incrimináveis (MISSE, 
2010) a partir do que os agentes observam em seus cotidianos. Quando forçavam a representação do acusado como um "doente mental", o colocavam em outro lugar, que não aquele atribuído aos "bandidos", esses, sim, considerados sujeitos matáveis e matadores, por assim dizer. Bruno era um pós-graduando em um curso de matemática, tinha uma família de trabalhadores, pontos estes muito relevantes. $\mathrm{O}$ mestrado se afigurava com algo bastante importante, pois criava uma semelhança com Daniel, que também havia estudado fora. Depois vim a saber, em conversas com meus interlocutores, que a semelhança não parava por aí. Tanto o defensor quanto o réu viveram infâncias pobres. $\mathrm{O}$ pai do defensor havia sido "feirante", como ele mesmo me explicou ao longo de nossa convivência. Os "estudos" eram, desse modo, uma forma de ascensão social para ambos.

\section{SOBRE VÍTIMAS, RÉUS E MORTES: SOBRE VALORES MORAIS, MORALIDADES E HIERARQUIZAÇÕES}

Procurei, através da explicitação dos casos trazidos nesse artigo, ilustrar como réus e vítimas são classificados de formas distintas em razão de construções morais sobre suas vidas, gerando uma classificação também quanto a suas mortes, as quais acabam por ser avaliadas e tratadas de maneira hierarquizada durante a administração de conflitos no contexto do Tribunal do Júri. José Leandro e Bruno, Maria e "Jorge do Posto" eram réus e vítimas que mobilizavam representações até antagônicas, fazendo com que o julgamento de tais mortes acionasse valores morais e envolvesse moralidades específicas, embora levando os casos a fins até semelhantes.

O réu Bruno, por ser estudante de pós-graduação, um menino "de família", só poderia estar nesse lugar se fosse "doente". Por sua escolaridade, por todas as características apresentadas em plenário, só seria capaz de cometer um crime em razão de um desvio mental. Por tal motivo, as perguntas dos agentes giravam em torno da moléstia e, ainda, os pedidos deles em seus discursos se fundamentavam nessa premissa. Tanto Bruno quanto José Leandro surgiam, na 
rotina dos agentes, como "semelhantes" e, nesse sentido, geravam certa empatia. Inclusive, a sentença proferida por Marcos classificava o primeiro expressamente como tal, quando dizia "não conseguimos aceitar que um semelhante a nós tenha tamanha crueldade". Nesse sentido, ele não merecia a mesma punição de um "bandido", mas uma medida de segurança e "tratamento" psiquiátrico. Quanto à morte causada por ele, vítima e réu foram descritos, ambos, como parte de uma "tragédia" em que as duas famílias "perderam seus filhos", quase um azar. Por isso o julgamento naquele dia era "diferente!”. Tratava-se de um "erro", de um "equívoco" e não de um crime comum. A imagem construída, especialmente pelo defensor público, era a de que não haveria no crime uma motivação, apenas um ônus, que teve como resultado a interrupção de duas vidas: Bruno pela doença, José Leandro, pela morte.

O contraste desse com o caso de Maria apresenta inúmeros eixos de diferenciação dos binômios réu/vítima, nos dois processos. No que se refere à morte da "cracuda", termos pejorativos eram usados para tratar de vítima e réu: "Jorge do Posto" "também não é flor que se cheire, já respondeu a vários processos". Aqui, a vítima, uma dependente química, teria escolhido o seu fim por toda sua trajetória. O réu, portanto, teria apenas cumprido o seu papel, fazendo a "limpeza social" do local e, quando sua personalidade foi contraposta à vítima (mulher que não cumpria o seu papel de mãe, usava drogas, perambulava pelo território com suas amigas e desacompanhada de seu marido), tornou-se menos incriminável (MISSE, 2010). Com isso, a figura de Maria da Silva perde força no lugar de vítima, ao mesmo tempo que o lugar de criminoso/incriminado de "Jorge do Posto" também. Assim, a "cracuda", por oposição ao caso de Bruno, também se apresentava como um "outro", um "diferente" dos agentes do Estado. E, como disse o promotor, a vítima não lhe inspirava "credibilidade nenhuma". Ora, nem mesmo depois de morta, Maria era tratada como humana. Faltava-lhe "credibilidade" para isso, por ser "drogada", "beber sozinha e com as amigas" e ter abandonado alguns de seus filhos, como sugeriam as versões sobre sua vida no inquérito e no processo.

Por tudo isso, em ambos os casos havia convergência moral entre os agentes quanto aos fins dos processos, em razão das representações das 
personalidades dos envolvidos, que podiam ser claramente assumidas e demonstradas aos jurados por meio dos seus discursos, ao sustentar suas teses sem qualquer impedimento moral. Embora, por outro lado, os "acordos" das sustentações não fossem explicitados, exceto quanto à publicização da "convergência dos pedidos".

O ponto é que, a partir das referidas construções morais, surgia uma hierarquização correspondente entre pessoas matáveis e outras nem tanto, por assim dizer, tal como o trabalho sobre as mortes de travestis já demonstrou (CARRARA; VIANNA, 2006). Ainda, o lugar onde se morre, como no caso de Maria, afeta não apenas a elucidação do crime por parte da polícia e as respectivas linhas de investigação para solucioná-lo, ao associar mortes a territórios (MEDEIROS, 2018), como também produz efeitos morais. A morte da "cracuda" em uma área "de milícia", afigura-se como algo comum, já que "esse tipo de pessoa não é aceita onde tem grupos de extermínio", como dizia o promotor.

Outro elemento que ganha destaque nos julgamentos morais produzidos nesses dois casos é a figura da "família" dos envolvidos, que foi trazida pelas falas dos agentes, dotada de diferentes sentidos. Os agentes se referiam tanto à família de Bruno e José Leandro quanto à família da "cracuda" como um valor moral (BALBI, 2007) que delineia decisões e informa as práticas dos agentes do poder judiciário quando estes analisam os casos. Ter ou não ter "família" era um elemento sopesado ao darem tratamento aos processos e também ao atribuírem qualidades a essas famílias.

No entanto, as representações que faziam delas eram muito diferentes. Enquanto os estudantes "tinham família", eram meninos "de família", ambas presentes em plenário e mencionadas nas falas dos agentes, Maria da Silva teve "nove filhos" de "pais diferentes", um companheiro com o qual "saiu para beber" $\mathrm{e}$ que voltou sozinho para casa, enquanto ela, a "cracuda", foi encontrar uma amiga para continuar "bebendo" ou "usando drogas". Nesse sentido, os relacionamentos afetivo-sexuais da mulher também ocupam um lugar de relevo para o delineamento do perfil da vítima. Surge, no seu caso, uma representação de ser mulher que não atende aos padrões esperados. Assim, os aspectos de gênero cumprem, desta forma, uma função central nesse processo (FACHINETTO, 2011). 
Ainda no que concerne à categoria família como valor moral balizador do julgamento, o fato de uma das filhas da "cracuda" ter sido criada "desde os nove meses" por aquela que foi a principal testemunha do caso em fase policial, sua ex-cunhada, foi um ponto ressaltado no inquérito e em plenário, aportando assim mais elementos de avaliação moral. A "cracuda" era caracterizada de maneira implícita como uma mãe descuidada, à semelhança do que já foi mostrado por Eilbaum (2011) em seu trabalho sobre a administração da morte de um bebê no conurbano bonaerense. Assim, as duas construções de "famílias" são contrastivas, embora sejam ambas norteadas pelos mesmos valores morais que partem de um certo modelo de família. Ao analisar tais representações, evidencia-se a manipulação de um modo de existir considerado como o correto e adequado na visão dos agentes, que também varia de acordo com os envolvidos nos casos.

Todas essas justificativas morais também equacionavam a relação entre o fundo e a forma jurídicas ${ }^{25}$ (RENOLDI, 2008) e permitiam chegar a resultados práticos, soluções possíveis (VILLALTA; CIORDIA, 2011) desejadas pela acusação e defesa em razão da convergência moral. Significa que, em ambos os casos, os valores morais da acusação e da defesa em relação aos fatos e suas posições quanto àquilo que réus e vítimas mereciam confluíam, construindo uma moralidade situacional (EILBAUM, 2012) comum que se orientava num mesmo sentido. Nos dois julgamentos, essa concordância se traduziu em "convergência de pedidos", no entendimento que o direito atribui ao termo: tanto a acusação quanto a defesa expuseram aos jurados os mesmos pleitos jurídicos, produzindo "acordos".

No caso de Maria, o fundo consistia na absolvição de um réu que fizera "limpeza social", matando uma vítima considerada menos importante, uma indesejada no local onde vivia. Era preciso dar forma jurídica para realizar o pedido de absolvição do homem, que emergiu por meio da alegada "ausência

\footnotetext{
${ }_{25}$ Para a autora, o processo pode ser compreendido por seu fundo e forma. O primeiro, em termos jurídicos, diz respeito às questões de "direito", isto é, o "mérito", que são as questões centrais do caso, os "direitos" e os "fatos". A forma, a seu turno, é procedimental, em acordo com o que dizem as categorias jurídicas (RENOLDI, 2008). Meu trabalho mostra, no entanto, que no contexto do Júri, não raro a forma é subvertida ou adequada para dar conta do fundo de acordo com as interpretações dos agentes. De modo que se nota menos uma separação desses aspectos e mais uma conexão entre eles, como também mostrou EILBAUM, 2012.
} 
de provas". Naquele momento, então, a "inexistência" delas se afigurou em uma justificativa técnica, de forma, para dar sentido a um pedido de absolvição sustentado pelo Ministério Público.

No entanto, essa escolha técnica contrasta com a que é feita em outros julgamentos, cujo conjunto probatório é apontado como de baixa qualidade, mas que tem como réus traficantes ou "bandidos" ilustres. Nesses processos, os promotores de justiça entendem que há meios para a condenação. E, ainda mais, a tese da acusação é sustentada "com carga". Isto é, casos em que homens como Fernandinho Beira Mar figuram como réus, mesmo face à inexistência de "indícios" ou "provas", ou mediante a sua insuficiência, os promotores sustentam a condenação (NUÑEZ, 2017). E o fazem em razão dos acusados serem famosos no "mundo do crime", portanto também uma justificativa moral. No mesmo sentido, como demonstra o trabalho de Figueira (2008), isso só é possível em razão de as provas serem menos importantes no processo oral do júri, de modo que podem ser usadas, tanto pela acusação quanto pela defesa, de modo igual para sustentar os respectivos argumentos.

Já no caso de Bruno e José Leandro, para não condenar um "menino" que cometeu um "erro" e causou uma "tragédia", ambos concordavam com a sua "inimputabilidade". Por isso também confluíam as suas performances, permitindo que externalizassem as moralidades e o acordo informal, porém por meio da adoção de sua forma jurídica: a "convergência de pedidos" nas suas falas para os jurados. Assim, quando os valores morais dos agentes convergem, surge a possibilidade de explicitação clara dos valores morais e, por vezes, a revelação do acordo, de modo que podem falar sobre ele e fazem o ritual apenas para cumprir a formalidade, levando a cabo o julgamento e dando conta da forma.

\section{CONCLUSÃO}

A Constituição Federal Brasileira diz que "todos são iguais perante à lei" (art. $5^{\circ}$ ) e, por isso, a todos é garantida a "inviolabilidade do direito à 
vida". O que o trabalho de campo que fiz por um ano e meio no Tribunal do Júri do Rio de Janeiro me mostrou é que, na prática, há vidas e vidas, ou certas vidas mais precárias (BUTLER, 2011) do que outras, garantindo um tratamento desigual a réus e vítimas. Tratamento esse que é determinado não de maneira igualitária, mas em contexto e em ação a partir da constatação da desigualdade de status entre os cidadãos (OLIVEIRA, 2011). Ainda, algumas vidas sofrem um "esvaziamento do humano", quer pela mídia, quer por parte dos discursos dos agentes do Estado, como procurei demonstrar neste artigo. No caso do Brasil e, mais especificamente, no Rio de Janeiro, os meios de comunicação reforçam, em razão da guerra às drogas, "aquilo que será e não será humano, o que será uma vida humana habitável, o que será uma morte passível de ser lamentada" (BUTLER, 2011). No caso de Maria, era também essa característica que esvaziava a condição humana de sua vida.

A convergência moral no caso Bruno Eusébio levou a um acordo quanto à "humanidade" desse sujeito, expressamente citada nas falas dos agentes, permitindo, então, que ele fosse considerado um "igual" que meramente apresentou dificuldades emocionais para lidar com as exigências e demandas da vida adulta e acadêmica. Por isso merecia ter sua pena atenuada, ainda que fosse condenado. Ele não "merece estar encarcerado", pois, assim, "estaríamos trocando um futuro pela sua conduta”, como sustentou Daniel.

Já a vida de Maria, a "cracuda", "uma pessoa de desafetos" que "por ingratidão roubou a amiga!”, não merecia o mesmo status. Ela era uma mulher, por assim dizer, matável. Um defunto ruim, com quem não se gasta vela. Com esse juízo moral, o judiciário separa quais mortes, ou quais mortos, merecem "justiça", como diziam os meus interlocutores. Tudo isso porque as moralidades situacionais (EILBAUM, 2012) acionadas determinam a forma como as vítimas e os "réus" são vistos pelos agentes e como seus casos são administrados. Este movimento é fundamental para o surgimento de convergências morais (NUÑEZ, 2018) que levarão à solução dos casos, seja esta a "condenação" ou "absolvição" dos acusados, sempre posicionando uns como mais iguais do que os outros. 


\section{REFERÊNCIAS BIBLIOGRÁFICAS}

1. BALBI, Fernando A. De leales, desleales y traidores: valor moral y concepción de política en el peronismo. Buenos Aires: Antropofagia, 2007.

2. BISHARAT, George. The plea bargain machine. Revista Dilemas, Rio de Janeiro, v. 7, n. 3, p. 767-795, 2014. Disponível em: http://bit.ly/3aeGwRp. Acesso em: 2 abr. 2015.

3. BRITO, Wagner. A celeridade processual: uma pesquisa empírica nos cartórios judiciais da capital do Rio de Janeiro. Rio de Janeiro: Autografia, 2017.

4. BUTLER, Judith. Vida precária. Contemporânea, Salvador, v. 1, n. 1, p. 13-33, 2011.

5. CARRARA, Sérgio; VIANNA, Adriana. “Tá lá o corpo estendido no chão...”: a violência letal contra travestis no município do Rio de Janeiro. Physis, Rio de Janeiro, v. 16, n. 2, p. 233-249, 2006.

6. DUMONT, Louis. Homo Hierarquicus: o sistema de castas e suas implicações. São Paulo: Edusp, 1997.

7. DURKHEIM, Emile; MAUSS, Marcel. Algumas formas primitivas de classificação. In: MAUSS, Marcel. Ensaios de Sociologia. 2. ed. São Paulo: Perspectiva, 2009. p. 399-455.

8. EILBAUM, Lucia. Familia, Justicia y Moralidades en el conurbano bonaerense. Anthropológicas, Recife, v. 22, p. 5-33, 2011.

9. EILBAUM, Lucia. “O bairro fala”: conflitos, moralidades e justiça no conurbano bonaerense. São Paulo: Hucitec, 2012.

10. EILBAUM, Lucia; LIMA, Roberto Kant; MEDEIROS, Flávia (org.). “Casos de repercussão": perspectivas antropológicas sobre rotinas burocráticas e moralidades. Rio de Janeiro: Consequência, 2017.

11. ESTUDANTE confessa que matou colega a facadas... Globoplay, Rio de Janeiro, 27 out. 2012. Disponível em: https://globoplay.globo.com/v/2212151/. Acesso em: 2 jan. 2017.

12. FACHINETTO, Rochele Fellini. A produção dos discursos de gênero nos julgamentos pelo Tribunal do Júri em Porto Alegre/Rio Grande do Sul/ Brasil. E-cadernos CES, [s. l.], v. 14, p. 33-60, 2011.

13. FERREIRA, Letícia Carvalho De Mesquita. Pessoas desaparecidas: uma etnografia para muitas ausências. Rio de Janeiro: Ed. da UFRJ, 2015.

14. FIGUEIRA, Luiz Eduardo. O ritual judiciário do Tribunal do Júri. Porto Alegre: Sérgio Antonio Fabris Editor, 2008. 
15. GEERTZ, Clifford. O saber local: novos ensaios sobre antropologia interpretativa. 9. ed. Petrópolis: Vozes, 2007.

16. GLUCKMAN, Max. O material etnográfico na antropologia social inglesa. In: ZALUAR, Alba (ed.). Desvendando máscaras sociais. Rio de Janeiro: Francisco Alves, 1975. p. 63-76.

17. KANT DE LIMA, Roberto. A polícia da cidade do Rio de Janeiro: seus dilemas e paradoxos. 2. ed. Rio de Janeiro: Forense, 1994.

18. KANT DE LIMA, Roberto. Da Inquiriçãa ao Júri, do Trial by Jury à Plea Bargaining: modelos para a produção da verdade e a negociação da culpa em uma perspectiva comparada Brasil/Estados Unidos. Tese (Concurso de professor titular de Antropologia) - Universidade Federal Fluminense, Niterói,1995.

19. KANT DE LIMA, Roberto. Sensibilidades jurídicas, saber e poder: bases culturais de alguns aspectos do direito brasileiro em uma perspectiva comparada. Anuário Antropológico, Brasília, DF, v. 2, p. 25-51, 2010.

20. LACERDA, Paula. Pesquisando em contextos de violência e de luta política: sofrimento, adesão e solidariedade. In: CASTILHO, Sérgio; LIMA, Antônio Carlos de Souza; TEIXEIRA, Carla Costa (org.). Antropologia das práticas de poder. Rio de Janeiro: ContraCapa: Laced, 2014. p. 91-113.

21. MEDEIROS, Flávia. Matar o morto: uma etnografia do Instituto Médico-Legal do Rio de Janeiro. Niterói: EdUFF, 2016.

22. MEDEIROS, Flávia. "Linhas de investigação": uma etnografia das técnicas e moralidades sobre "homicídios" na região metropolitana do Rio de Janeiro. Rio de Janeiro: Autografia, 2018.

23. MIRANDA, Ana Paula Mendes de. Cartórios: onde a tradição tem registro público. Antropolítica, Niterói, n. 8, p. 59-75, 2000.

24. MISSE, Michel. Crime, sujeito e sujeição criminal: aspectos de uma contribuição analítica sobre a categoria "bandido". Lua Nova, São Paulo, v. 79, p. 15-38, 2010.

25. MISSE, Michel. Violência e teoria social. Dilemas, Rio de Janeiro, v. 9, n. 1, p. 45-63, 2016.

26. NUÑEZ, Izabel Saenger. "Latrocínio" e "Homicídio": uma distinção processual que separa "criminosos" e pessoas "que cometeram um crime". Confluências Revista, Niterói, v. 17, n. 2, p. 128-149, 2015.

27. NUÑEZ, Izabel Saenger. "Se fosse a Madonna não seria tudo isso!": um julgamento evento no Tribunal do Júri do Rio de Janeiro. In: LIMA, Roberto Kant de; EILBAUM, Lucía; MEDEIROS, Flávia (org.). "Casos de repercussão": perspectivas antropológicas sobre rotinas burocráticas e moralidades. Rio de Janeiro: Confluências, 2017. v. 1. p. 25-34. 
28. NUÑEZ, Izabel Saenger. “Aqui não é casa de vingança, é casa de justiça!”: moralidades, hierarquizações e desigualdades na administração de conflitos no Tribunal do Júri. Tese (Doutorado em Antropologia) -Universidade Federal Fluminense, Niterói, 2018.

29. OLIVEIRA, Roberto Cardoso de. O trabalho do antropólogo: olhar, ouvir, escrever. Revista de Antropologia, São Paulo, v. 39, n. 1, p. 13-37, 1996.

30. OLIVEIRA, Luís Roberto Cardoso de. Concepções de igualdade e cidadania. Contemporânea, São Carlos, v. 1, n. 1, p. 35-48, 2011.

31. RENOLDI, Brigida. Narcotrafico y Justicia en Argentina: la autoridad de lo escrito en el juicio oral. Buenos Aires: Antropofagia, 2008.

32. SARTI, Cynthia. Corpo, violência e saúde: a produção da vítima. Sexualidad, Salud y Sociedad, Rio de Janeiro, n. 1, p. 89-103, 2009.

33. SARTI, Cynthia. A vítima como figura contemporânea. Caderno CRH, Salvador, v. 24, n. 61, p. 51-61, 2011.

34. SCHRITZMEYER, Ana Lúcia Pastore. Controlando o poder de matar: uma leitura antropológica do Tribunal do Júri - ritual lúdico e teatralizado. Tese (Doutorado em Antropologia) -Universidade de São Paulo, São Paulo, 2001.

35. THUM, Tássia. Estudante confessa assassinato de colega e diz que sofria bullying. G1, Rio de Janeiro, 26 out. 2012. Disponível em: https://glo.bo/2RhSjpD. Acesso em: 2 jun. 2017.

36. VEIGA, Cilmara. Entre datas, marcas e registros burocráticos: os múltiplos tempos de um processo criminal em um caso de crime em série. Confluências, Niterói, v. 17, p. $35-54,2015$.

37. VILlALTA, Carla; CIORDIA, Carolina. Administrando soluciones posibles: medidas judiciales de protección de la niñez. Avá, Posadas, v. 18, p. 111-131, 2010.

38. ZALUAR, Alba. Um debate disperso: violência e crime no Brasil da redemocratização. São Paulo em Perspectiva, São Paulo, v. 13, n. 3, p. 3-17, 1999. 